\title{
Allergic diseases of the skin and drug allergies - 2012. Is there association between duration of seasonal alleric rhinitis and oral allergy syndrome?
}

\author{
Reza Faridhosseini, Farahzad Jabbari, Afshin Shirkani", Mohammad Reza Zandkarimi, Hadis Yousefzadeh
}

From 2nd WAO International Scientific Conference (WISC 2012)

Hyderabad, India. 6-9 December 2012

\section{Background}

Oral allergy syndrome (OAS) characterized by oral IgEMediated symptoms, which is caused by cross-reactivity between proteins in pollen and fresh fruit or vegetables . Association between oral allergy syndrome and duration of seasonal allergic rhinitis, is not well known.

\section{Methods}

In this cross sectional study, 103 consecutive patients with seasonal allergic rhinitis were enrolled. Sensitization to common aeroallergen confirmed by skin prick test 3 millimeter more than negative control. Clinical symptoms, personal and familial history of atopy and demographic data were listed. According to food allergy history 63 of 103 patients had positive Open SingleBlind Oral Food Challenge Test that was associated with oral allergy syndrome.

\section{Results}

Among studied cases, 63 patients (61.2\%) with $28.8 \pm 10.6$ years old had OAS and 40 (38.8\%) with $26.8 \pm 13.2$ years had not OAS. We found that duration of seasonal allergic rhinitis in OAS group $(7 \pm 5.9$ years old $)$ and non OAS group ( $5 \pm 4$ years ) was significantly correlated $(\mathrm{P}=0.03)$.

\section{Conclusions}

In this study, duration of seasonal allergic rhinitis was associated significantly with oral allergy syndrome. However further studies with more sample sizes and double blind placebo methods might be need.

Mashhad University of Medical Science, Mashhad, Iran
Published: 23 April 2013

doi:10.1186/1939-4551-6-S1-P99

Cite this article as: Faridhosseini et al: Allergic diseases of the skin and drug allergies - 2012. Is there association between duration of seasonal alleric rhinitis and oral allergy syndrome? World Allergy Organization Journal 2013 6(Suppl 1):P99.
Submit your next manuscript to BioMed Central and take full advantage of:

- Convenient online submission

- Thorough peer review

- No space constraints or color figure charges

- Immediate publication on acceptance

- Inclusion in PubMed, CAS, Scopus and Google Scholar

- Research which is freely available for redistribution

Submit your manuscript at www.biomedcentral.com/submit 